\title{
ASTIN BULLETIN ONLINE
}

Many readers will already be aware that ASTIN Bulletin has a growing presence on the internet.

First, we are very grateful to the Casualty Actuarial Society for posting back issues of the Bulletin on their website at

\section{www.casact.org/library/astin/}

More recently a search engine has been developed on the IAA website

$$
\text { www.actuaries.org/public/en/ASTIN/bulletin.cfm }
$$

and this enables researchers to search by subject area, author or keywords in the title of the paper.

Both of these developments will provide actuaries worldwide with an excellent resource. 